\title{
Corrosion of tin can and its inhibition: A review
}

\author{
F.A. Ansari, ${ }^{1}$ Y.S. Siddiqui ${ }^{2}$ and M.A. Quraishi $^{3}$ \\ ${ }^{1}$ Department of Applied Chemistry, JETGI, Faculty of Engineering, Barabanki, 225203 \\ India \\ ${ }^{2}$ Department of Civil Engineering, JETGI, Faculty of Engineering, Barabanki, 225203 \\ India \\ ${ }^{3}$ Center of Research Excellence in Corrosion, Research Institute, King Fahd University of \\ Petroleum and Minerals, Dhahran 31261, Saudi Arabia \\ *E-mail: farhat.ansari@jit.edu.in
}

\begin{abstract}
Tin is a chemical element which is represented by the symbol $\mathrm{Sn}$. Tin is most commonly used in the form of tin cans. Food cans mainly store food stuff and used by packaging industry. The corrosion is a major problem in tin cans and a matter of great concern for the corrosion engineers as well as researchers. This article deals with corrosion behaviour of tin cans in different media and its inhibition. Researches which have been done on dissolution of tin in different types of canned products containing hydrochloric acid, tartaric acid, citric acid, maleic acid and formic acid have been described here since acids have a great tendency of dissolving the metal to which they come into contact. It has been found that artificial fruit juices and preservatives augment the rate of corrosion as compared to natural juices and acids. The comparative study of the rate of corrosion in tin cans under different conditions along with the techniques to determine the rate of corrosion has been studied The literature review on a wide range of corrosion inhibitors used to inhibit corrosion has been systematically carried out. The main purpose of this review is to showcase the various cases of corrosion mechanism and inhibition methodologies to combat corrosion of tinplate.
\end{abstract}

Keywords: tin can, tin plate corrosion, corrosion mechanism, corrosion inhibition.

Received: July 5, 2019. Published: October 12, 2019

doi: $\underline{10.17675 / 2305-6894-2019-8-4-3}$

\section{Introduction}

In general Tin is a non ferrous metal which finds wide use in making beverage cans, food cans, artistic cans and not only that but its application extends to manufacturing of electrical machinery parts etc. [1]. Tin has fine metallic lusture, quite resistance to corrosion and finds ease in several mechanical processes like soldering and welding. Now since tin cans are mostly used for preserving food and beverages, it has a tendency to get dissolved and mixed in the product which is to be preserved thereby causing many serious problems to human health like gastrointestinal disorders and other issues like toxicity to 
the consumers due to dissolution of tin metal in pickles and other acidic food items [2]. Tin can is widely used in packaging industry. The consumption of one-third of tin is used for the manufacturing of tin can. The manufacturing of tin with a varied application is consumed more than 2.5 million every year. It is reported that $25 \%$ of manufacturing is only for beverage tin cans. Industrial application of tin is limited by its low strength. Tin cans have a wide range of utility for packing foods, beverages, aerosol products which find it quite useful for preservation of food products and give long shell life [3].

\subsection{Historical background}

Tin was first used in Mesopotamia in $3500 \mathrm{BC}$ currently in Iraq. Peter Durand an Englishman in 1813 patented tin can. The usage of tin for various purposes has been since ages. In ancient times, about $40 \%$ of tin was blended with copper to make bronze alloy. In Eastern Mediterranean region the supply of tin was cut off to various civilizations. It was realized by Sumerians in $2050 \mathrm{BC}$ that if different ores could be blended together, especially with tin a different form of copper was formed which was easy to cast and comparatively harder. The antique of values of elements such as gold, silver, tin, copper, lead and mercury have been recognized.

\subsection{Economic importance}

Tin finds various applications in the automobile engine manufacturing industry. It is also applied as an internal coat/layer in food, beverage cans etc. The major countries which were the producer of tin were Malaysia, China, Bolivia and Indonesia. Tin can exports faced hikes by about $150 \%$ in agriculture [4]. As per analysis made by, tin will find wide range of applications in electric vehicles (EVs), robotics as well as renewable energy. The International Tin Association (ITA) forecasted that tin markets will sink by about 4 percent in 2019 as compared to what was in [5]. As a whole, tin metal will help to maintain the economic status of a country. Several countries including Nigeria have advanced their custom rules to increase revenue generation [6].

\subsection{Mechanism of corrosion in tin cans}

Tin plate basically consists of tin coated in the inner side of the steel plate (which is in contact with the canned product). Due to scratches, we find areas where Tin Iron alloy (FeSn alloy) is exposed and that becomes the prime area for corrosion to occur. Metals when exposed to air form an oxide film due to the reaction between steel, moisture and atmospheric oxygen which causes rusting of the metals leading to its destruction. The process of rust formation is quite complex which can be illustrated by a simple reaction.

$$
4 \mathrm{Fe}+\mathrm{H}_{2} \mathrm{O}+3 \mathrm{O}_{2}=2 \mathrm{Fe}_{2} \mathrm{O}_{3} \cdot \mathrm{H}_{2} \mathrm{O}
$$


The corrosion rate depends on the food item which is preserved in it. The base metal of tin can is steel which acts as a cathode and tin which is the inner most portions subjected to food as in case of tin can acts as an anode. The rate of corrosion highly depends upon the type of food product, composition, grade of tin plate. In presence of sulfur dioxide, sulfite and oxygen the rate of corrosion accelerates and are more harmful to the can products. Numerous studies have revealed that dissolution of tin into the canned product involves the evolution of hydrogen [7]. The products which contain acids cause formation of complexes which ultimately result in destruction of tin metals [8-13].

\subsection{Factors affecting corrosion}

Several factors affect the rate of corrosion of tin plate [14-17] which include:

1. Composition of material (grain size, surface morphology, base steel etc.)

2. Type and nature of coating i.e. epoxy, polyester, acrylic resin etc.

3. Canned product (food, beverages, and storage conditions)

4. Temperature and duration of storage

5. Can processing techniques which include cleaning, canning, exhausting, sealing and sterilizing.

If the content of oxygen is disturbed the growth of bacteria will increase and shelf life of canned food will be reduced. Under the adequate processing parameters, abnormal content of oxygen and spoilage bacteria will flourish in the can containers, and thus the shelf life of canned food will be shortened [18].

Tin as a highly workable and also was once as valuable metal like silver for making jewellery, coins, and special dishware. Nowadays, it is used in manufacturing of sheets and various construction materials, for soldering or joining metal parts, for storage containers, and in alloys like bronze and Babbitt metal.

Tin is an element of Group IV with four valence electrons, so it yields both divalent and tetravalent oxides and ions but preference is for the tetravalent species [19]

$$
\begin{array}{ll}
2 \mathrm{SnO}_{2} \rightarrow 2 \mathrm{Sn}+2 \mathrm{O}_{2} & \Delta G^{0}=-586513+215.6 T(\mathrm{~J} / \mathrm{mol}) \\
\mathrm{Sn}^{4+}+2 \mathrm{e}^{-} \rightarrow \mathrm{Sn}^{2+} & \Delta E^{0}=+0.15 \mathrm{~V}(\mathrm{SHE}) \\
\mathrm{Sn}^{2+}+2 \mathrm{e}^{-} \rightarrow \mathrm{Sn} & \Delta E^{0}=-0.136 \mathrm{~V}(\mathrm{SHE})
\end{array}
$$

Tin is quite stable, it undergoes passivation due to the formation of $\mathrm{SnO}_{2}$. Tin dioxide $\mathrm{SnO}_{2}$ has a rutile structure i.e. close packed structure and it is electropositive in nature. 


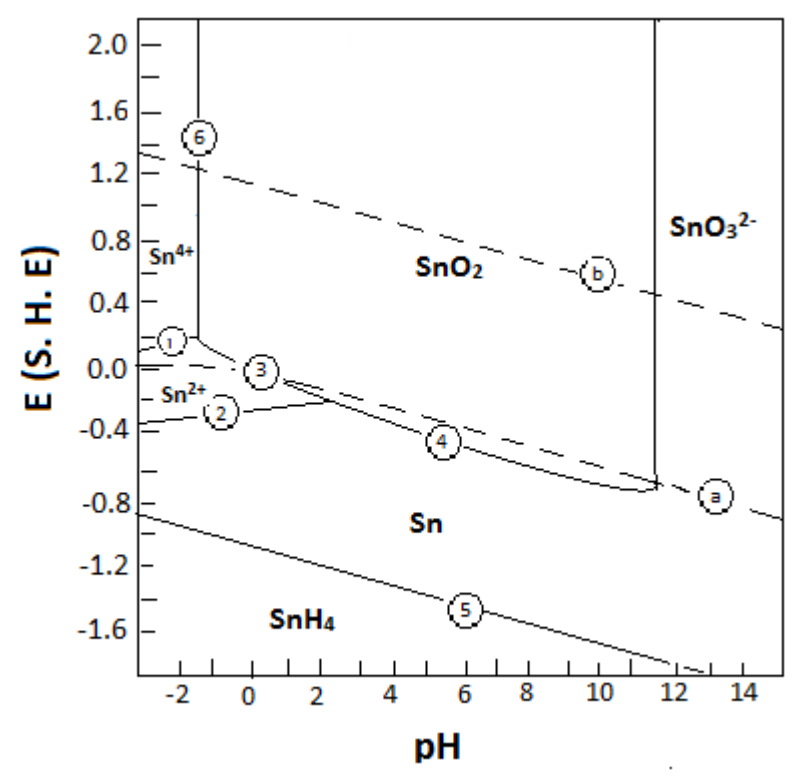

Figure 1. Pourbaix diagram of $\mathrm{Sn}-\mathrm{H}_{2} \mathrm{O}$ at $25^{\circ} \mathrm{C}\left(\mathrm{SnH}_{4}\right.$ is volatile in nature $)$.

The Pourbaix diagram of tin-water system shows regions of "Immunity" i.e. the resistance of a particular metal towards corrosion as it not attacked by the environment; likewise "Corrosion" the pattern of chemical attack and "Passivity" the formation of oxide layer which further retards corrosion. This plot basically shows the immunity of a particular tin metal in a specified environment and its tendency to corrode. In this context the plot shows tin behaviour at different $\mathrm{pH}$. The Pourbaix diagram, for tin-water system at $25^{\circ} \mathrm{C}$ clearly predicts corrosion resistance in mild aqueous media, although the domain of stability of tin and water do not overlap in the $\mathrm{pH}$ range $0-14$, corrosion current are limited by the passive surface, which resist the access of dissolved oxygen [19]:

$$
\mathrm{O}_{2}+2 \mathrm{H}^{+}+2 \mathrm{e}^{-}=\mathrm{H}_{2} \mathrm{O}
$$

And higher hydrogen over potential prevents hydrogen evolution;

$$
2 \mathrm{H}^{+}+2 \mathrm{e}^{-}=\mathrm{H}_{2}
$$

The bivalent $\mathrm{Sn}(\mathrm{II})$ shows a second oxide phase. The $\mathrm{Sn}(\mathrm{II})$ oxidation is quite sensitive, therefore the passivation of tin is mostly regarded due to the rutile structure of the dioxide [20].

\section{Internal corrosion of tin cans}

The use of tin coating on the inner surface of cans is to protect the steel which is a cathode. The tin on the inner surface acts as a sacrificial anode. Small pores and fractures on the tin surface leads to corrosion as oxygen penetrate via these pores and allow rusting of steel. Y. Che [21] et al. conducted potentiostatic measurements and found that corrosion of tinplate undergoes a three stage anodic process. Under anaerobic conditions, the tin has to 
be anodic to steel. The stages (Figure 2) involves nucleation followed by a growth of a passive oxide layer i.e. the first stage, second stage involved pit nucleation and the third stage showed re-passivation. Corrosion generally occurs in three stages [17]:

1. In the first stage, the dissolution of tin occurs through nucleation which is followed by growth of passive oxide layer.

2. During the second stage, the pores and scratches increase in their sizes due to dissolution of tin thereby exposing the cathodic steel making it more prone to corrosion. This stage consumes a lot of time as it is slow and gradual.

3 . The final stage represents the end of shelf life of tin can as large area of tin is being dissolved in the canned product [22-24].

(a)
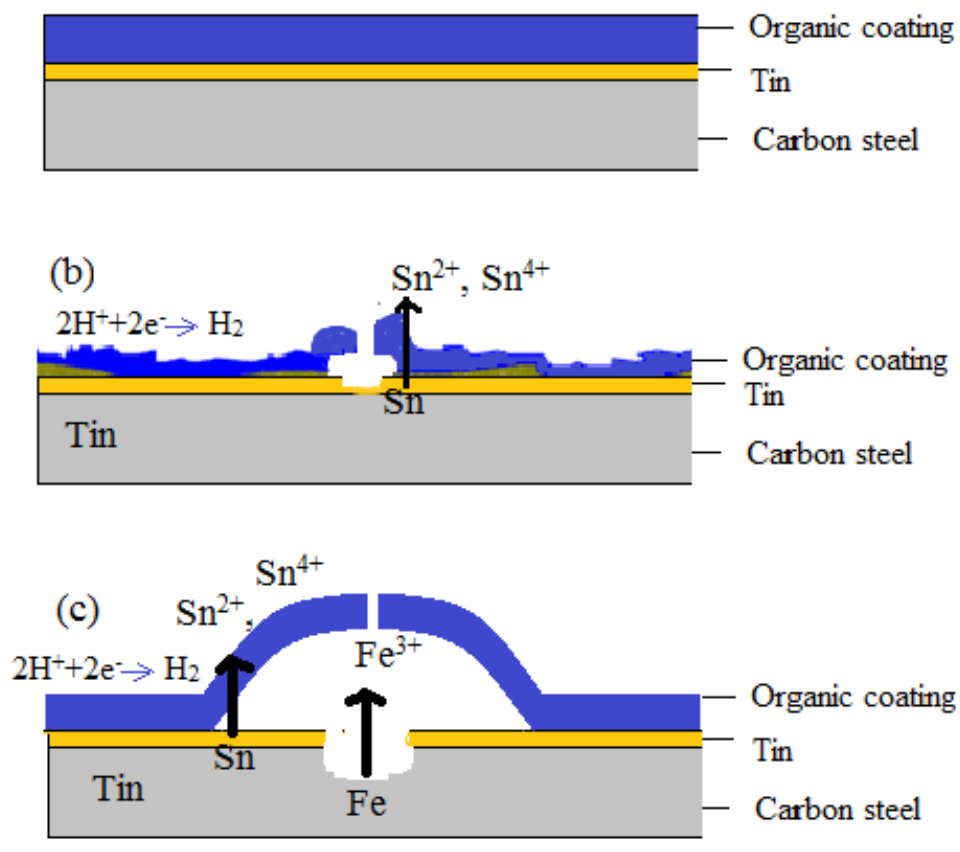

Figure 2. Tin plate corrosion.

\subsection{Types of corrosion}

There are basically three types of corrosion encountered by tin cans which is categorized as:

a) Filiform corrosion: It occurs under the thin coatings of tin and distributes throughout the tin film like little threadlike fragments. They usually bulge or crack the coating.

b) Pitting corrosion: Occurs in a specific surface area. It basically occurs due to sticking of the dirt particles on the surface. Crevice corrosion, water line attacks and concentration cell corrosion also takes place in tin cans. 
c)Erosion corrosion: It is a long term phenomena i.e. it takes place over a long period of time. Erosion commences with a tiny air bubble and then slowly continues [16].

\subsection{Dissolution of tin in different types of canned products}

The canned products which are acidic in nature allow the tin can material to get dissolved in them thereby causing toxicity as well as gastrointestinal disorders to the consumers. However the safe limits for tin dissolution in the canned product are of main concern to the corrosion engineers. The tin can corrosion decides the shelf life of the tin can [25].

When fruit juices are stored in tin cans corrosion occurs as formation of complexes takes place like formation of oxalic acid, citric acid, maleic acid etc. Food colorants, preservatives artificial flavors also affect the rate of corrosion of tin. The reason behind this is that two or more sulfuric acid groups that form soluble compounds are present in beverages, fruit juices etc. Hydroxyl groups present also increase the corrosion rate of tin [26].

\section{Behavior of tin in different types of media}

Various researches have been conducted round the globe, which reveals the behaviour of tin in different media, i.e. acids, salts and natural fruit juices etc. The various analytical techniques and surface studies have been employed in order to assess the corrosion rate under different concentration.

\subsection{Acids}

\subsubsection{Tartaric acid}

Rabab M. El-Sherif et al. [27] studied the electrochemical behaviour of tin metal in tartaric acid solution at different concentrations using amino acids like alanine, glycine, glutamic acid and histidine which acted as environmental friendly corrosion inhibitors. Electrochemical techniques adopted for analysis were potentiodynamic polarization and electrochemical impedance spectroscopy (EIS). The analysis was carried out by using Scanning Electron Microscope (SEM). The study reflected that there was an augmentation in tin can dissolution with an increase in Tartaric acid concentration, as the anodic behaviour of tin was responsible for its active and passive transition as the E/I curves were revealing.

\subsubsection{Citric acid}

E.E. Foad et al. [28] analysed the electrochemical behaviour of tin at various concentrations of citric acid solutions ranging from 0.1 to $1.0 \mathrm{M}$ with the implementation of cyclic voltametric technique under different conditions. The potentiodynamic polarization curves were plotted and it showed anodic behaviour of tin exhibiting 
active/passive transition. The anodic dissolution of tin increased substantially due to the addition of $\mathrm{Cl}, \mathrm{Br}$ or I ions. The potentiodynamic polarization curve in the presence of three polyethylene glycols indicated that these three polymers used showed good inhibition efficiency. G. Bereket et al. [29] also analysed the behaviour of tin in citric acid at $\mathrm{pH}$ and $\mathrm{pH} 6$ in concentrations of $10^{-1}$ and $10^{-4} \mathrm{M}$. $I_{\text {corr }}$ values substantially decreased from $10^{-1}$ and $10^{-4} \mathrm{M}$ concentrations. YChe et al. found that in case of an aerated citric acid solution, the shape of EIS spectra displayed a characteristic with two time constants after three days [21].
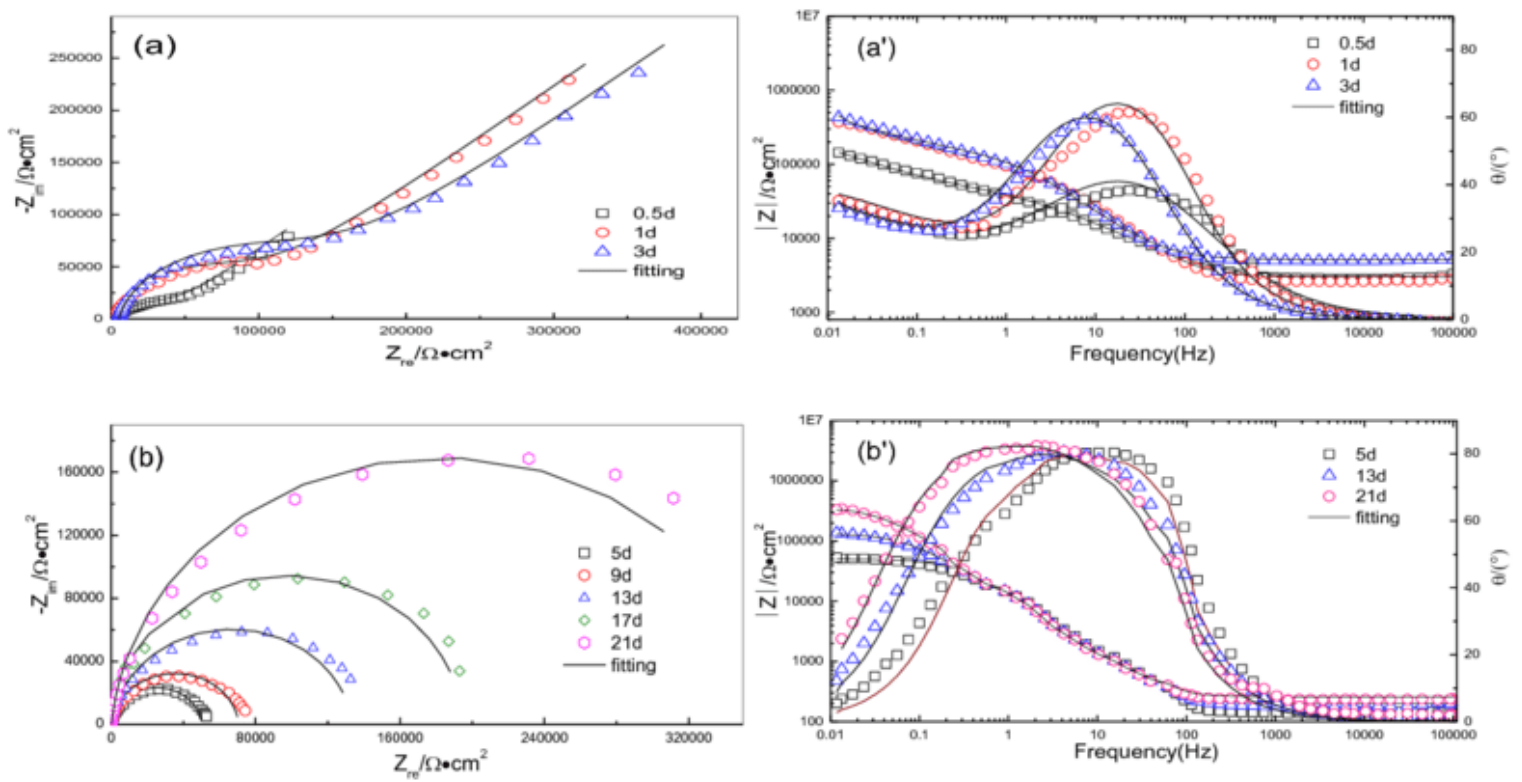

Figure 3. Corrosion mechanism differences of tinplate in aerated and deaerated citric acid solution.

\subsubsection{Maleic Acid}

B.O. Adewuyi et al. [30] analysed the corrosion of tin in aqueous medium which contained food colourants of various types (Sunset yellow, Carmosine, Tartazine and Poncreau 4R). Various types of sweeteners were also employed like Glycerol, Saccharin, Sucrose as well as glucose. They found that the corrosivity of acid containing artificial colours faces augmentation by addition of colourants and increase in acid concentration as well. But if the colourant concentration is kept constant and acid concentration is gradually increased, the order of corrosion for different colourants changes. as it used to be for increasing acid and colour concentrations. Sweeteners were found to act as inhibitors to corrosion [2325]. 


\subsubsection{Acetic acid}

The corrosion rate of tin can in the presence of acetic acid $\left(\mathrm{CH}_{3} \mathrm{COOH}\right)$ was studied, where the concentration ranges from $2 \mathrm{M}-10.3 \mathrm{M}$ by polarization technique $[31,32]$. The studies revealed a linear relationship between corrosion potential $\left(E_{\text {corr }}\right)$ and corrosion current $\left(I_{\text {corr }}\right)$ $v s$ acetic acid at low pH. H.H. Hassan et al. [32] studied the corrosion behaviour of tin plate in acetate buffer by three different techniques. The pit formation starts when the electrode potential shifts to more anodic region and solution becomes more concentrated. Meanwhile the nucleation rate increases and growth rate decreases.

\subsubsection{Formic acid}

S. Koyama et al. [33] analysed the effect of formic acid surface formation on the bond strength of Solid state bonded interfaced Tin which was analysed by SEM. Interfacial microstructures and fractures were observed. Solid state bonding process was being carried out in a vacuum chamber at bonding temperatures of $403-473 \mathrm{~K}$ at $7 \mathrm{MPa}$ pressure with $1800 \mathrm{~s}$ bonding time. The analysis showed an increase in bond strength with the increase in bonding temperature. As surface modification took place, the bonded joints were found at low temperatures ( $40 \mathrm{~K}$ less than the typical bonding temperature) which resulted in the destruction of oxide film and augmentation in tensile strength.

\subsubsection{Fruit juices}

With the help of a weight loss technique, morphology and structures of corrosion products were deeply analysed with the aid of scanning electron microscope (SEM). When tin plate specimens of different weights were immersed in different kinds of synthetic fruit juices with preservatives, natural fruit juices and water for a period of 20 days. The weight loss was observed and noted at six day intervals. The studies revealed that artificial fruit juices with preservatives were more corrosive as compared to natural fruit juices and water due to the reason that it had high acidity $[3,26]$.

\subsubsection{Hydrochloric acid}

The dissolution of tin in $\mathrm{HCl}$ is slow in the absence of oxygen due to hydrogen displacement. When the sample is immersed into air-saturated $\mathrm{HCl}$, tin dissolution takes place due to evolution of hydrogen. As the concentration of tin in the solution increases, corrosion displays auto-catalytic behaviour with corrosion rate proportional to the square of stannic concentration $[34,35]$.

\subsubsection{Sulfuric acid}

The study done through rotating-disk voltammeter showed anodic dissolution and partial passivation of tin in 4.5-8 M sulphuric acid. The study also revealed a Tafel slope of 
$1 /(30 \pm 3) \mathrm{mV}^{-1}$ in the active dissolution. This behaviour was independent of acid concentration. A reaction mechanism explained this slope. The behavior of tin was in its bivalent form and it gets dissolved in both active as well as passive potential region. The surface studies like SEM, XRD, XPS and SIMS depicted that the film was composed of tin oxide [36].

\subsection{Alkaline or neutral media}

Most common of all salts i.e. common salt $(\mathrm{NaCl})$ also shows inhibitory effects when mixed with nitrates and nitrites. At high temperatures, $\mathrm{NaCl}$ mixed with nitrates and nitrites show corroding properties. K. Galic et al. [14] performed an analysis by Auger electron spectroscopy and X-ray photo spectroscopy and got the polarization curves for tin electrode in $\mathrm{NaCl}$ environment. An anodic polarization of $400 \mathrm{mV}$ made some identical changes. A.J. Bard et al. [15] found that an anti corrosion film was formed when $\mathrm{NaCl}$ was replaced with $\mathrm{SnCl}_{2}$. The tinplate behaviour highly depends on the nature of the electrolyte. The coated tinplate evolution is different, as well. The impedance decreases with immersion time in both types of electrolytes and no passivation is observed.

The studies revealed the possibility of attack on tin by solutions of high $\mathrm{pH}$ values (above 10.5). The position of this limit is influenced by the following factors;

a) Temperature

b) Composition of the solution, and

c) Condition of metal surface.

Corrosion will occur if the surface oxide is significantly soluble especially at $\mathrm{pH}=12$. As corrosion starts, the rate of corrosion is governed by the oxygen supply as well as temperature and is not greatly affected by the character of the alkali. The removal of oxygen from alkaline solutions can be done by adding sodium sulfite (oxygen scavanger), can very well prevent corrosion until unless tin is in contact with another metal, like steel, from which hydrogen evolution takes place. If some oxidizing agents is being added, they augment the rate of corrosion but too much amount is added, then it creates passivity forming a layer of chromium oxide [37, 38].

\subsection{Coffee}

Wang Ke et al. [39] studied the behaviour of tin cans containing coffee. It was investigated by the use of novel electrochemical impedance and electrochemical noise sensor. The study revealed that there was an increase in iron and tin with the storage time. The corrosion mechanism of corrosion in tinplates with coffee was discussed by the morphology of corroded surface done by optical microscopy and scanning probe microscopy. The results also revealed, that with the prolongation time the the coating resistance, charge transfer resistance and noise resistance decreases. 
With the extension of the storage time, the EIS characteristics showed significant changes, varying from a feature of one capacitive loop to 2 capacitive loops. The graphs clearly reveal that the general shape of the impedance only includes impedance response of a degradation process of the organic coatings.
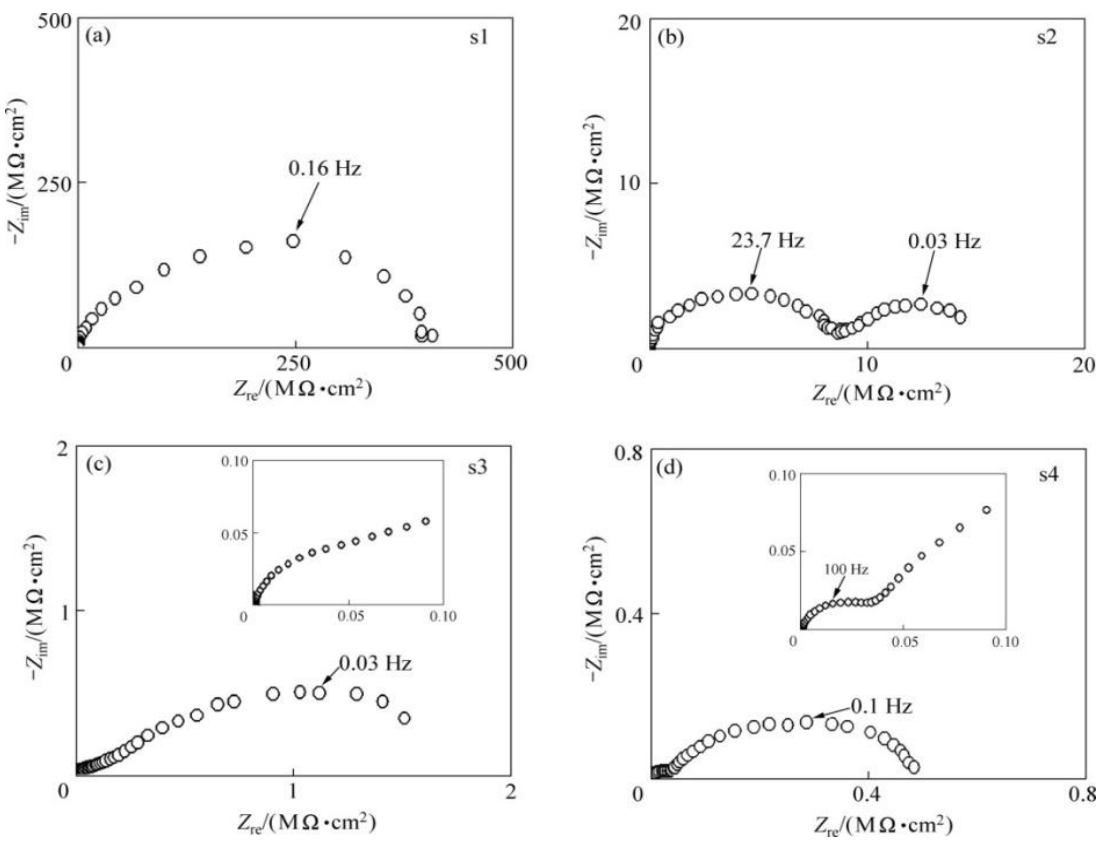

Figure 4. EIS plots of beverage cans with different storage time: (a) 1 month; (b) 3 months; (c), (d) 12 months.
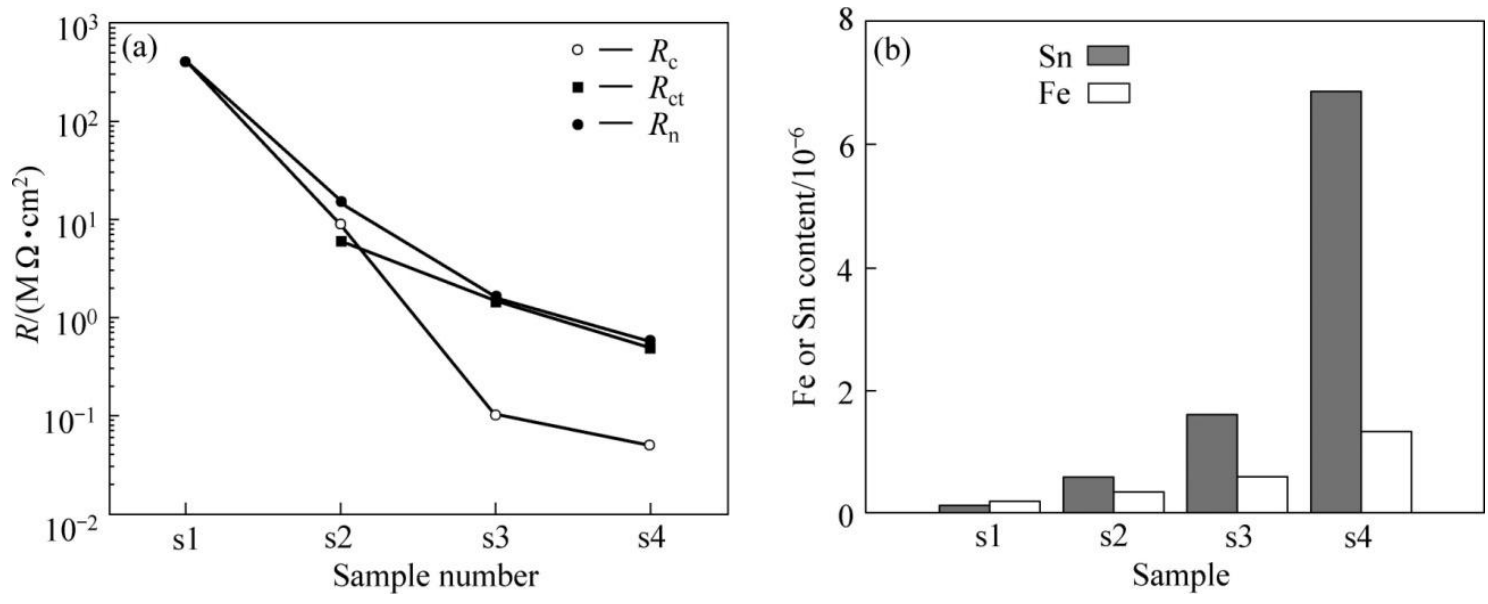

Figure 4 (a). Correlation between electrochemical parameters (noise resistance $R_{\mathrm{n}}$, coating resistance $R_{\mathrm{c}}$ and charge transfer resistance $R_{\mathrm{ct}}$ (b) Tin and iron contents in cans. 


\section{Tin plate corrosion mechanism in aerated and deaerated media}

The various researches done on tin plate corrosion oxygen play a very important role in this process. Tin plate corrosion is basically dependent on the nature of electrolyte to which it is exposed. Deaerated systems decreases the corrosion resistance whereas aerated systems increases the corrosion resistance. The large increase in polarization resistance and cathodic resistance in the aerated solutions proves to be a good inhibitor in the presence of oxygen. Bastidas et al. [40] analysed four substrates namely pure tin, tin plate, alloy layer and bare steel in citrate solutions $(\mathrm{pH}=6)$ in aerated as well as deaerated media with inclusion and exclusion of inhibitor. A sodium salt of alkenyl succinate was employed as an inhibitor. The techniques adopted for carrying out studies were polarization curves, polarization impedance and resistance. The outcomes of the studies revealed that the corrosion inhibitor was active in the aerated media in the case of bare steel. Oxygen was found to be great relevance in tinplate corrosion process. The $R_{\mathrm{p}}$ and $R_{\mathrm{ct}}$ values are one degree higher in de aerated media as compared to aerated media. After 10 to $24 \mathrm{hrs}$ time, the increment in $R_{\mathrm{p}}$ and $R_{\mathrm{ct}}$ values (with inhibitor) represented a good steel tin inhibitor.

\section{Techniques for determination of tin corrosion in canned foods}

The metallic dissolution is through internal corrosion in tin cans which involves electrochemical reactions. Various techniques are being employed for the determination of tin which are discussed below.

\section{1}

UV/VIS spectrophotometry, which involves testing of tin plate corrosion under the same conditions which will be countered by the inner side of the tin plate after storage of food products [41] conducted a research and found that a combination of some chemicals like nonyl phenoxy polyethoxyethanol (OP), bromopyrogallol red (BPR) and cetyltrimethylammonium bromide (CTAB) had shown absorbtion peak at $304 \mathrm{~nm}$.

\section{2}

Measurement of Polarization Resistances Sweep, recorded that methods like electrical impedance spectroscopy (EIS). The method of impedance spectroscopy is a powerful tool for investigation of electrical properties of materials and interfaces of conducting electrodes [42], electrical resistance, gravimetric mass loss, quartz crystal microbalance based mass loss etc. determine interfacial reaction rates due to corrosion and also determines polarization rates which includes step or sweep, current step or sweep, impedance spectroscopy, electrochemical noise etc. Beverage cans ( $250 \mathrm{ml}$ capacity) were tested using electrochemical sensor and EIS was done. 


\section{3}

Other methods like X-ray fluorescence spectrometry also determine the quality of tin and its behaviour in corrosive media. Y. Mino [43] used X-ray spectrometry with a rhodium Xray tube to determine tin. Electrochemical sensor (Figure 3) was developed by Da-Hai Zia [44] of three electrodes along with a contactor to connect the electrode to the sensor.

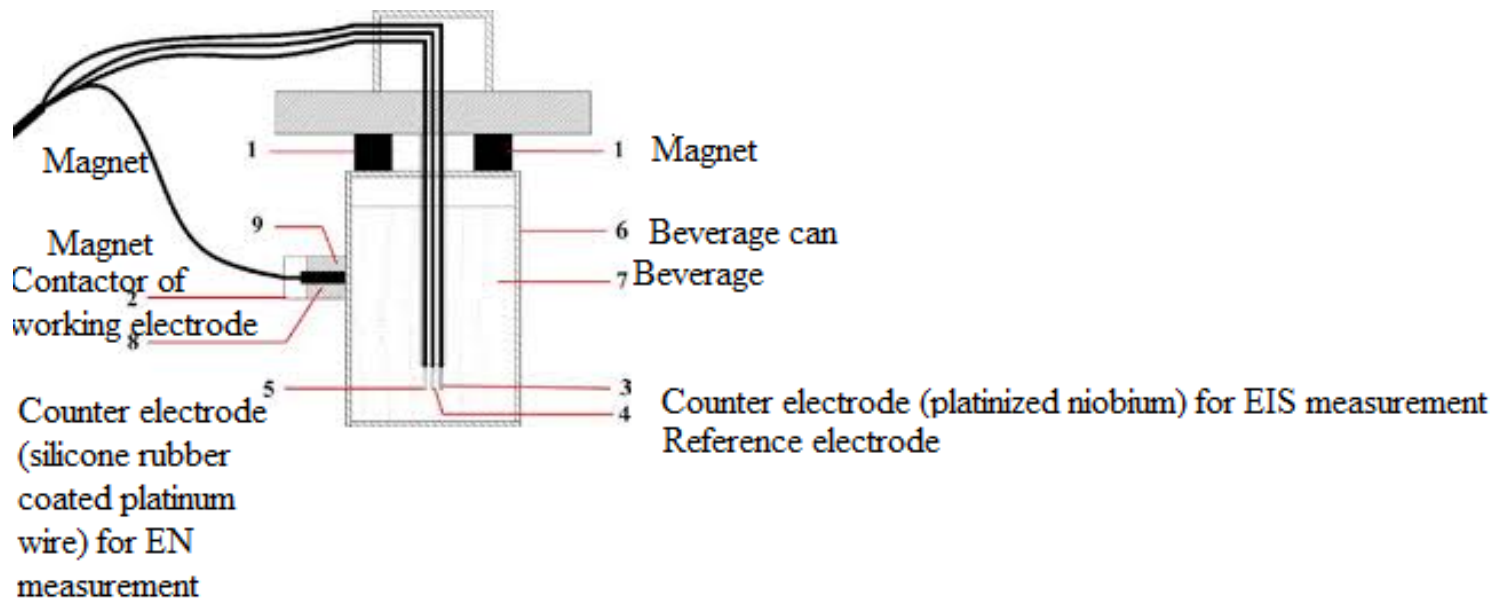

Figure 5. Electrochemical sensor for corrosion detection.

\section{Various corrosion inhibitors for tin can corrosion}

The Table 1 below represents the various corrosion inhibitors used in different media like $\mathrm{HCl}, \mathrm{HNO}_{3}, \mathrm{NaCl}$, citric acid, tartaric acid etc. Weight loss, polarization techniques, thermometric techniques, FTIR and NMR spectroscopy, EIS were used in the analysis of corrosion mechanism and inhibition. A variety of corrosion inhibitors like essential onion oil, dioctyl sebacate oil, epoxy phenolic lacquers, natural honey and black radish juice, cerium, sodium lauryl sulphate etc. were used and showed respective corrosion inhibition efficiencies at different conditions.

Table 1. Various corrosion inhibitors used in different corrosive medium.

\begin{tabular}{ccccc}
\hline S.No & Medium & Inhibitor used & Method & Ref. \\
\hline 1 & NaCl solution & $\begin{array}{c}\text { Essential onion oil } \\
\text { dioctyl sebacate oil } \\
\text { epoxy phenolic lacquers } \\
\text { Cerium }\end{array}$ & $\begin{array}{c}\text { Weight loss and } \\
\text { polarization }\end{array}$ & {$[45]$} \\
2 & $\mathrm{NaCl}$ solution & EIS & {$[46]$} \\
3 & Cirtic acid & $\begin{array}{c}\text { Arginine, lysine, cysteine } \\
\text { hydrochloride }\end{array}$ & Weight loss and EIS & {$[47-49]$}
\end{tabular}




\begin{tabular}{|c|c|c|c|c|}
\hline S.No & Medium & Inhibitor used & Method & Ref. \\
\hline 4 & $\mathrm{NaCl}$ solution & $\begin{array}{l}\text { Natural honey and black } \\
\text { radish juice }\end{array}$ & $\begin{array}{l}\text { Weight loss and } \\
\text { polarization techniques }\end{array}$ & {$[50]$} \\
\hline 5 & $\mathrm{NaCl}$ solution & Bioorganic tomato peel & $\begin{array}{l}\text { FTIR and NMR } \\
\text { spectroscopy }\end{array}$ & {$[51]$} \\
\hline 6 & Tartaric acid & Azadirachta indica & EIS & [27] \\
\hline 7 & $\mathrm{HCl}$ and $\mathrm{HNO}_{3}$ & Carrageenan compounds & $\begin{array}{l}\text { Weight loss and } \\
\text { thermometric techniques }\end{array}$ & {$[52]$} \\
\hline 8 & $\begin{array}{l}\text { Hydrochloride } \\
\text { solution } \\
(0.5 \mathrm{M} \mathrm{HCl})\end{array}$ & Natural artemisia oils & Potentiostatic polarization & {$[53]$} \\
\hline 9 & $\begin{array}{l}0.5 \mathrm{M} \mathrm{HCl} \\
\text { solution }\end{array}$ & $\begin{array}{c}\text { Thymus satureioides (TS) } \\
\text { oil }\end{array}$ & $\begin{array}{c}\text { Potentiodynamic } \\
\text { polarization and } \\
\text { polarization resistance } \\
\text { measurements }\end{array}$ & [54] \\
\hline 10 & Nitrates & Sodium lauryl sulphate & Acid products & {$[55]$} \\
\hline 11 & $\begin{array}{l}\text { Anaerobic } \\
\text { corrosion }\end{array}$ & $\begin{array}{l}\text { Chrysanthemin victoria } \\
\text { plums and raspberries }\end{array}$ & EIS & {$[56]$} \\
\hline 12 & $\mathrm{NaCl}$ solution & $\begin{array}{l}\text { Amino acids and } \\
\text { vitamin } C\end{array}$ & EIS & {$[57]$} \\
\hline 13 & Fruit juices & Additives & $\begin{array}{l}\text { Scanning Electron } \\
\text { Microscopy (SEM) }\end{array}$ & {$[3]$} \\
\hline 14 & $\begin{array}{l}\text { Citric chloride } \\
\text { solution }\end{array}$ & Amino acids & EIS & {$[58]$} \\
\hline 15 & $\mathrm{NaCl}$ & Polyacrylamide & Polarization technique & [59] \\
\hline
\end{tabular}

\section{Various research reports on use for various inhibitors}

A.N. Grassino et al. did a research and found that the use of Essential Onion Oil (EOO) improves the protects the tinplate as compared to dioctyl sebacate oil (DOS), and was found to be as effective as epoxy phenolic lacquers. The addition of EOO was recommended by the researchers due to the cost of canned food being economical and also with regards to enhanced organoleptic properties maintaining a temperature lower than $36^{\circ} \mathrm{C}$ [45]. Scanning electron microscopy (SEM) and energy dispersive spectroscopy analysis were performed and they revealed that location of cerium precipitates totally depend on the distribution of the cathodic areas that may form a continuous layer over the surface it may precipitate in the mechanical failures. This analysis was carried out by M.A. Arenas et al. [46]. 
M.A. Quraishi et al. [47-49] found that nitrogen containing amino acids show great inhibition efficiency of about $70 \%$ at $5 \mathrm{ppm}$ and sulphur containing amino acids $69 \%$ and $56 \%$ efficiency at $50 \mathrm{ppm}$ concentration respectively. Effect of natural honey (chestnut and acacia), as well as natural honey with black radish juice on tin can corrosion in $\mathrm{NaCl}$ and aqueous media by using weight loss and polarization techniques. The study revealed that inhibition efficiency of acacia honey had a lower value than that of chestnut honey, while the addition of black radish juice augmented the inhibition efficiency of both honey varieties. A multi-layer adsorbed film was formed on the surface of tin [50]. Pectin is an efficient corrosion inhibitor having efficiency of about $73 \%$ even at lower concentrations, far better than commercially available pectin. As far as chemical profile, rheological properties and structural characterisation of extracted pectin is concerned, tomato peel prove to be a suitable source for pectin isolation. Furthermore results compiled show that under-utilised biomass waste from tomato canning industry can be applied for development of new generation of corrosion inhibitors [51].

L. Bammou et al. [52] analysed the behaviour of corrosion of tin plate in $\mathrm{HCl}$ and addition of natural Artemisia essential oil at different concentrations and temperatures. Some observations were that increase in temperature stimulated the corrosion of tin in $\mathrm{HCl}$. Addition of $\mathrm{AO}$ caused reduction of corrosion of tin plate. As the concentration of $\mathrm{AO}$ was increased, the corrosion inhibiting efficiency also increased. The best value of inhibition efficiency was $81 \%$ at a temperature of $298 \mathrm{~K}$ at $0.5 \mathrm{~g} / 1 \mathrm{AO}$ concentration. The inhibitor adsorption completely follows Langmuir isotherm [53]. Thymus satureioides (TS) oil can be used as an effective green corrosion inhibitor in $\mathrm{HCl}$ medium. At $6 \mathrm{~g} / \mathrm{l}$ concentration the inhibition efficiency was found to be $87 \%$. At higher temperatures $\left(65^{\circ} \mathrm{C}\right)$ the inhibition efficiency drops to $75 \%$ [54].

Sodium lauryl sulphate is found to have a strong inhibiting effect at a concentration of $5 \mathrm{ppm}$. The effect of nitrate was squashed at $30 \mathrm{ppm}$ concentration. The anionic surfactants caused negative potential and promoted corrosion inhibition whereas cationic surfactants promoted corrosion of tin. J.C. Sherlock [55] studied the behaviour of surfactants on the dissolution of tin. The addition of anionic surfactants created a negative shift of potential and inhibited corrosion but cationic surfactant caused a positive shift and stimulated corrosion. Further, the role of sodium lauryl sulphate was also investigated at a concentration of $5 \mathrm{ppm}$ and at $30 \mathrm{ppm}$, it showed a strong inhibitive effect. The presence of surfactant also suppressed the accelerating effect nitrate in tin dissolution.

The extract of Victoria plums and raspberries contains a major constituent chrysanthemin, the main colouring matter, it had been found to act as a cathodic depolarizer for the corrosion of tin by citric and maleic acids [56]. Amino acids like glycine, serine [57], methionine, vitamin $\mathrm{C}$ and some other binary mixtures mitigated the dissolution of tin in $3.5 \% \mathrm{NaCl}$ solution. The presence of $50-100 \mathrm{mM}$ glycine and methionine showed improvement in passive behaviour of tin, while serine also inhibited tin 
dissolution but in comparison at a higher concentration i.e. at $100 \mathrm{mM}$. Methionine showed a better protection of tin than cystenine and vitamin $\mathrm{C}$. The potential-current curves of tin in a de-aerated solution of citric-chloride solution $(\mathrm{pH}=5)$ showed that the cathodic reaction was controlled by the reduction of proton and also a metal-inhibitor complex $\mathrm{Sn}-\mathrm{H}_{\mathrm{cit}}$ was being formed. It was revealed that arginine proved to be the best inhibitor among the studied compounds. Arginine in the concentration range of $10^{-2} \mathrm{M}$ proved to be an effective corrosion inhibitor with $81 \%$ inhibition efficiency and behaved as cathodic inhibitor [58].

Two polymers [59] i.e. polyacrylamide and polypropenoyl glycine were investigated by et al. using potentiodynamic polarization technique. Three samples of polyacrylamide having different molecular weights were being tested at ( 0.5 to 30$) \mathrm{ppm}$ concentrations at $20^{\circ} \mathrm{C}$ in $1 \mathrm{M} \mathrm{NaCl}$ sol. On the other hand, one sample of polypropenoyl glycine having same degree of polarization as that of one sample of polyacrylamide having lowest molecular weight. The results showed that among the 3 samples of polyacrylamide, the sample having lowest molecular weight showed the highest inhibition efficiency, and the sample having highest molecular weight accelerated the rate of corrosion of tin can. Same case was for the polypropenoyl glycine sample as its molecular weight was also very low like the one showing good inhibition efficiency.

\section{Conclusions}

This entire review makes it clear that tin dissolution mostly take place when it comes on contact with acids present in the canned products, like citric acid, maleic acid, oxalic acid, hydrochloric acid etc. Fresh juices do not cause large amount of corrosion but juices, beverages and other canned products containing artificial colours and sweeteners accelerate the rate of corrosion. This problem of tin can corrosion can be tackled by the use of various organic as well as inorganic inhibitors as this paper reflects various tests performed under different conditions like SEM, EIS, weight loss etc. A wide range of corrosion inhibitors like essential onion oils, dioctyl sebacate oil, epoxy phenolic lacquers, Natural honey and black radish juice, cerium, sodium lauryl sulphate, Natural Artemisia Oils, Amino acids etc. were used and proved to be effective corrosion inhibitors.

\section{References}

1. S. Blunden and T. Wallace, Tin in canned food: a review and understanding of occurrence and effect, Food Chem. Toxicol., 2003, 41, 1651-1662. doi: 10.1016/s02786915(03)00217-5

2. A. Palmieri, A. Montanari and G. Fasangaro, Detinning corrosion in canned tomatoes, Proceeding of second North American Steel packaging conference, 2002, Oct 15-16, Rosemount, Illinois, USA. 
3. N.A-G. Abdel-Rahman, Tin-plate corrosion in canned foods, J. Global Biosci., 2015, 4, 2966-2971.

4. https://punchng.com/tin-can-records-150-increase-in-agro-exports/Business \& Economy, January 3, 2018.

5. P. Barrera, Tin Outlook 2019: A Bright Year Ahead?, December 31st, 2018. Available on https://investingnews.com/daily/resource-investing/industrial-metals-investing/tininvesting/tin-outlook/

6. http://businessupdate.com.ng/tincan-customs-introduces-new-tools-to-increaserevenue-generation-2/, April 29, 2018.

7. D. Sourajyoti and M.K. Agrawal, Investigation of corrosion behaviour of tinplate in fruit juice, IACSIT Int. J. Eng. Technol., 9, 234-242. doi: 10.21817/ijet/2017/v9i3/170903S036

8. P.W. Board and R.J. Steele, Diagnosis of corrosion problems in tinplate food cans, Technical Paper No. 41, CSIRO Division of Food Research, 1975, Sydney, Australia.

9. A.L. Breedlove and D.R. Davis, Effect of selected organic acids on the pitting of tinplate cans in Model Systems, J. Food Sci., 1983, 48, 1148-1150. doi: 10.1111/j.1365-2621.1983.tb09179.x

10. S.C. Britton, Tin Versus Corrosion, 1975, ITRI Pub. No. 510, International Tin Research Institute, Middlesex, England.

11. C. Mannheim N. Passy and A.L. Brody, Internal corrosion and shelf-life of food cans and methods of evaluation, Crit. Rev. Food Sci. Nutr., 1982, 17, 371-407. doi: $\underline{10.1080 / 10408398209527354}$

12. M. Edwards and N. May, Metal Cans, In: Food Packaging Technology, Eds.: R. Coles, D. Mcdowell and M.J. Kirwan, 2003, Blackwell Publishing, Oxford, UK.

13. G.L. Robertson, Food Packaging: Principles and Practice, 1993, Marcel Dekker INC., New York.

14. K. Galic, M. Pavic and N. Pikovic, The effect of inhibitors on the corrosion of Tin in Sodium chloride solution, Corros. Sci., 1994, 36, 785-795. doi: 10.1016/0010938X(94)90170-8

15. A.J. Bard, R. Parson and J. Jordan, Standard potentials in aqueous solution, 1985, Marcel Dekker Inc., pp. 127, 213-220.

16. T. Leah, Types of corrosion for a tin plate, 2012, Available on http://www.ehow.com/list_5982123_types_corrosion_tin_plate.html\#ixzz1xsSaqCn6

17. Da-Hai-Xia, Deterioration process and corrosion detection of metal packaging materials, $\mathrm{PhD}$ thesis, 2012.

18. W.L. Landry, A.H. Schwab and G.A. Lancette, Bacteriological Analytical Manual, Chapter 21A, Examination of Canned Foods, 2001.

19. S. Lyon, 2.12 - Corrosion of tin and its alloys, Shreir's Corrosion, 2010, 3, 20682077. doi: 10.1016/B978-044452787-5.00099-8 
20. D.E.J. Talbot and J.D.R. Talbot, Corrosion Science and Technology, CRC Press, 2018.

21. Y. Che, Z. Han, B. Luo, D. Xia, J. Shi, Z. Gao and J. Wang, Corrosion mechanism differences of tinplate in aerated and deaerated citric acid solution, Int. J. Electrochem. Sci., 2012, 7, 999-1007.

22. C. Mannheim and N. Passy, Internal corrosion and shelf-life of food cans and methods of evaluation, Crit. Rev. Food Sci. Nutr., 1982, 17, 371-407. doi: 10.1080/10408398209527354

23. G. Kamm, Progress in materials for can stocks and future trends, ISIJ Int., 1989, 29, no. 7, 614-624.

24. G. Milanese, A. Montanari, R. Massini, and A. Cassará, Sperimentazione e applicazione di un metodo per valutare il ferro esposto sulle bande stagnate, Ind. Conserve, 1984, 59, 120-124.

25. S. Blunden and T. Wallace, Tin in canned food: a review and understanding of occurrence and effect, Food Chem. Toxicol., 2003, 41, 1651-1662. doi: 10.1016/s0278-6915(03)00217-5

26. J. Rawat and M.A. Quraishi, Corrosion of tin in fruit juices and its inhibition, Bull. Electrochem., 2003, 19, 467-470.

27. M. Rabab, El-Sherif and W.A. Badawy, Azadirachta indica as a green corrosion inhibitor, Int. J. Electrochem. Sci., 2011, 6, 6469-6482.

28. E.E. Foad, El Sherbini and E. Hamed, Corrosion behaviour of tin in citric acid solutions and effect of some inorganic and organic compounds, Mater. Sci.: Indian J., 2009, 5, 347-355.

29. G. Bereket and A. Yedigun, Corrosion behaviour of tin electrode in citric acid, maleic acid and glutamic acid, Commun. Fac. Sci. Univ. Ankara, Ser. B: Chem. Chem. Eng., 1991, 37, 81-94. doi: 10.1501/Commub_0000000445

30. B.O. Adewuyi and O.A. Oladunjoye, Corrosion of tin plate by maleic acid colourants and sweetening agents, West Indian J. Eng., 2004, 27, 10-17.

31. G.K. Gomma, Corrosion of tin in acetic acid, Rev. Roum. Chim., 1996, 41, 717-723.

32. H.H. Hassan and K. Fahmy, Pitting corrosion of tin by acetate anion in acidic media, Int. J. Electrochem. Sci., 2008, 3, 29-43.

33. S. Koyama, Y. Aoki and I. Shohji, Effect of formic acid surface modification on bond strength of solid-state bonded interface of tin and copper, Mater. Trans., 2010, 51, 1759-1763. doi: 10.2320/matertrans.MJ201019

34. E.A. Noor and A.H. Al-Moubaraki, Corrosion behaviour of mild steel in hydrochloric solutions, Int. J. Electrochem. Sci., 2008, 3, 806-818.

35. A.W.K. Lui, Dissolution of tin in hydrochloric acid, Electronic Theses and Dissertations, 1962, 6311. 
36. T. Laitinen, K. Salmi, G. Sundholm, P. Viinikka and A. Yli-Pentti, The anodic behaviour of tin in sulphuric acid solutions, Electrochim. Acta, 1992, 37, 1797-1803. doi: $10.1016 / 0013-4686(92) 85083-W$

37. S.C. Britton and K. Bright, Examination of oxide films on tin and tinplate, Metallurgia, 1957, 56, 163-168.

38. S.C. Britton and R.M. Angles, Improvement of corrosion resistance of tin plate by chemical treatment, J. Appl. Chem., 1954, 4, 351-364. doi: 10.1002/jctb.5010040703

39. W. Ke, W. Jihui, W. Huihui, F. Congwei, X. Da-hai, Z. Xin, D. Lihua and S. Jiangbo, Corrosion detection of tinplate cans containing coffee using EIS/EN sensor, J. Cent. South Univ. Technol., 2014, 21, 76-82.

40. J.M. Bastidas, J.J. Dambornea，J.A. Gonzalez，E. Otero， M.E. Chacon, W.I. Archer, J.D. Scantlebury and K. Alston, An electrochemical study on the influence of oxygen in tinplate corrosion and inhibition, Corros. Sci., 1990, 30, 171-182. doi: $\underline{10.1016 / 0010-938 X(90) 90071-C}$

41. X. Huang, W. Zhang, S. Han and X. Wang, Determination of Tin canned foods by UV/Visible spectrophotometric technique using mixed surfactants, Talanta, 1997, 44, 817-822. doi: 10.1016/S0039-9140(96)02119-4

42. F.A. Ansari and Y.S. Siddiqui, A review on corrosion problems in context to oil and gas industries and application of suitable corrosion inhibitors, Res. J. Recent Sci., 2018, 7, $1-5$.

43. Y Mino, Determination of Tin canned foods by X-ray fluorescence spectrometry, $J$. Health Sci., 2006, 52, 67-72. doi: 10.1248/jhs.52.67

44. D. Xia, X. Zheng, H. Wang and C. Fu, Detection of the corrosion degree of beverage cans using a novel electrochemical sensor, Anti-Corros. Methods Mater., 2013, 60, 153-159. doi: 10.1108/00035591311315382

45. A.N. Grassino, Z. Grabarić, A. Pezzani, G. Squitieri and K.J. Berković, Corrosion inhibition with different protective layers in tinplate cans for food preservation, J. Sci. Food Agric., 2010, 90, 2419-2426. doi: 10.1002/jsfa.4101

46. M.A. Arenas, A. Conde and J.J de Damborenea, Cerium: a suitable green corrosion inhibitor for tin plate, 2002, 44, 511-520. doi: 10.1016/S0010-938X(01)00053-1

47. M.A. Quraishi, F.A. Ansari and D. Jamal, Corrosion inhibition of tin by some amino acids in citric acid solution, Indian J. Chem. Technol., 2004, 11, 271-274.

48. J. Rawat and M.A. Quraishi, Corrosion of tin in fruit juices and its inhibition, Bull. Electrochem., 2003, 19, 467-470.

49. M.A. Quraishi and J. Rawat, Corrosion of tin cans and its inhibition, Food Sci. (Mysore), 2000, 37, 529-532.

50. I. Radojčić, K. Berković, S. Kovač and J. Vorkapić-Furač, Natural honey and black radish juice as tin corrosion inhibitors, Corros. Sci., 2008, 50, 1498-1504. doi: $\underline{10.1016 / j . c o r s c i .2008 .01 .013}$ 
51. A.N. Grassino, J. Halambek, S. Djaković, S.R. Brnčić, M. Dent and Z. Grabarić, Utilization of tomato peel waste from canning factory as a potential source for pectin production and application as tin corrosion, Food Hydrocolloids, 2016, 52, 265-274. doi: $10.1016 /$ j.foodhyd.2015.06.020

52. L. Bammou, M. Mihit, R. Salghi, A. Bouyanzer, S.S. Al-Deyab, L. Bazzi and B. Hammouti, Inhibition effect of natural artemisia oils towards tinplate corrosion in $\mathrm{HCl}$ solution: Chemical Characterization and Electrochemical Study, Int. J. Electrochem. Sci., 2011, 6, 1454-1467.

53. L. Bammou, B.R. Salghi, L. Bazzi and B. Hammouti, Thermodynamic properties of Thymus satureioides essential oils as corrosion inhibitor of tinplate in $0.5 \mathrm{M} \mathrm{HCl}$ : chemical characterization and electrochemical study, Green Chem. Lett. Rev., 2007, 3, 173-178. doi: $10.1080 / 17518251003660121$

54. J.C. Sherlock and S.C. Britton, Promotion by nitrates of the dissolution of tin by acids and its inhibition, $B r$. Corros. J., 1973, 8, 210-215. doi: $\underline{10.1179 / 000705973798321955}$

55. F.W. Salt and J.G.N. Thomas, The anaerobic corrosion of tin in anthocyanin solutions and fruit syrups, J. Appl. Chem., 1957, 7, 231-238. doi: 10.1002/jctb.5010070504

56. M.S.S. Morad and A.A.A Hermas, Influence of some amino acids and vitamin $\mathrm{C}$ on the anodic dissolution of tin in sodium chloride solution, J. Chem. Technol. Biotechnol., 2001, 76, 401-410. doi: 10.1002/jctb.397

57. M. Zerfaoui, B. Hammouti, H. Oudda, M. Benkaddour and S. Kertit, Corrosion inhibition of tin in citric-chloride solution by amino acids, Bull. Electrochem., 2004, 20, 433-437. doi: 10.1016/j.porgcoat.2004.05.005

58. S.M. Sayyah, S.S. Abd El-Rehim and M.M. El-Deeb, The effect of some polymers on the corrosion behaviour of tin in $1 \mathrm{M} \mathrm{NaCl}$ solution, Int. J. Polym. Mater., 2001, 49, 59-80. doi: 10.1080/00914030108035867

59. K.S. Khairou, A.A. Alfi and E.M. Mabrouk, Natural polymers as corrosion inhibitors for aluminium and tin in acidic media, Mater. Sci. Res. India, 2007, 4, 279-290. doi: $\underline{10.13005 / \mathrm{msri} / 040207}$ 